\title{
Predesign Evaluation of St. Petersburg State Polytechnical University Campus Energy Efficiency Measures
}

\author{
Anna Nefedova ${ }^{1}$, Julia Bykova ${ }^{2}$ Sergei Kosov ${ }^{3},{ }^{4}$ Nikolai Vatin, Aleksandrs Zajacs ${ }^{5}$, Anatolijs Borodinecs ${ }^{6}$, \\ ${ }^{1,2,4}$ Peter the Great St.Petersburg Polytechnic University, ${ }^{3}$ Ltd "Ecomatic SPb ${ }^{15,6}$ Riga Technical University
}

\begin{abstract}
This article describes the process and results of the first stage of work within the developed program of reconstruction of heating systems of the central platform of SPbSTU, according to the requirements of Federal Law No. 261-FZ of the Russian Federation "On energy saving and increase of energy efficiency".

Recent particular interest in energy efficiency in buildings and optimization of consumption of energy resources has determined the relevance of the work.

The potential for energy saving measures has been evaluated and a concrete plan for further steps has been developed in the second stage of the work.
\end{abstract}

Keywords - Automatic heating control, energy efficiency, building renovation.

\section{INTRODUCTION}

Nowadays energy efficiency has become a major theme in all aspects of life, including in construction. People are increasingly looking for the rational use of energy resources. The Government of Russia and other countries began to control circulation of energy resources more carefully and take measures for energy saving and energy efficiency [1]. Recently developed standards establish classes of energy efficiency of buildings, depending on their level of heat consumption, giving a similar task to individual elements of the building engineering systems. The essence of this problem is to choose the most energy-efficient equipment or technical solutions for each of the elements of the systems to optimize the consumption of energy resources [2].

In Russia, $20 \%$ of all energy is spent on ventilation, air conditioning and refrigeration; $45 \%$ of the total generated thermal energy is used in heating and heat supply systems. This explains the great attention that should be paid to the engineering systems in terms of energy saving [3].

Thus, most of all the question of energy conservation is attributed to heating. Within the reconstruction process of obsolete heating systems, old-fashioned jet pumps are replaced by modern automated individual heat substations with independent secondary loop and circulation pumps, which makes regulation process more precise and efficient.

"The St. Petersburg State Polytechnical University" together with Ltd "Ekomatik SPB" within the contract on joint activity were challenged by the optimization of work of the system of heat supply to the buildings belonging to the University. The task was set: to define what actions and in what sequence need to be carried out for energy efficiency increase.

\section{THE OVERVIEW}

Improving energy efficiency of heating systems has been widely discussed in modern works [4]-[9]. The example of the project for the reconstruction of heat supply system to improve energy conservation is given in [10] and [11] analyzed the economic feasibility of such projects. [12] contains an analysis of the heating systems of St. Petersburg and examples of energy-saving technologies for the reconstruction of thermal networks.

In [13], the importance of use of automatic control in thermal networks and installations for the organization of effective working hours of systems during all heating season and providing comfortable conditions in buildings was noted.

In article [14], the subsequent main directions for the reduction of heat consumption of the building were presented: increased thermal performance of buildings in the range of costeffective design tools and techniques of urban planning; the use of energy-efficient glazing; application of automated climate control facilities to ensure the best mode of spending thermal energy; the use of energy-saving technological schemes.

An essential factor in energy efficiency of the building is the work of the ventilation system. Therefore, special attention is paid to the operation of ventilation systems in historic buildings and how to update them to reduce power consumption [15], [16].

In the articles [17], [18], the analysis of modern ventilation systems - centralized natural exhaust ventilation systems and decentralized air intake and exhaust mechanical ventilation systems with plate heat exchangers - has been conducted. The analysis of the latter showed that it allows recuperating up to 85 $\%$ of heated exhaust air, not the heating energy. Heating energy is also consumed in transmittance of losses through the building envelope.

To evaluate the effectiveness of the building, it is necessary to conduct a survey to assess the condition of heating, electricity, and water supply. For example, [19], [20] contain the analyses of building energy consumption of budgetary organizations (kindergartens), and in [21] an energy audit of an educational building "Hydrotechnical building-2" of the SaintPetersburg State Polytechnical University is presented. 


\section{PURPOSES AND RESEARCH PROBLEMS}

The main purpose of the work is drafting of recommendations and development of the program for reconstruction of heat supply of the Central platform buildings of $\mathrm{SPbSTU}$

\begin{tabular}{|l|l|} 
I stage & $\begin{array}{l}\text { Collection, analysis and data processing for the } \\
\text { preparation of the performance specifications to } \\
\text { make further calculations; }\end{array}$ \\
\hline II stage & $\begin{array}{l}\text { Calculations and selection of the equipment, } \\
\text { development of design solutions; }\end{array}$ \\
\hline $\begin{array}{l}\text { Economic calculations and development of the } \\
\text { program of reconstruction. }\end{array}$
\end{tabular}

The main objective includes three stages:

The purpose of this article is to describe the work done within the first stage. To achieve this purpose, the following tasks are formulated:

\section{DESCRIPTION OF THE RESEARCH}

For such a project, accuracy and reliability of the collected information is very important, as it has a direct impact on all the technical calculations and, therefore, the choice of measures to improve the energy efficiency of the buildings. Therefore, in addition to direct data collection it is necessary to carry out data checks.

\section{Tasks of the I stage:}

-To make the full list of buildings of the campus;

- To provide the description of the chosen buildings;

- To create the list of technical parameters (initial data) necessary for further calculations and to carry out data collection on each building;

- To analyse the reliability of the collected data and to make relevant amendments if necessary;

- To execute a preliminary estimate of the possible economic potential from introduction of energy saving actions;

- To formulate a conclusion about the results of the first stage and to prepare performance specifications to complete the following stage of works.

\section{A. Description of the campus of SPbSTU}

29 buildings are located at the campus of SPbSTU: 3 multifamily buildings, and the rest are educational buildings. Average mode of operation of the educational buildings: MonFri 9:00-18:00, Sat-Sun closed. Buildings are connected to the same source heating - boiler house belonging to the University, which is dedicated only to provide heat to its facilities; 10 buildings are connected to the municipal heating network. Thus, we have a full, closed heating system with own heat supply source, networks and consumers.

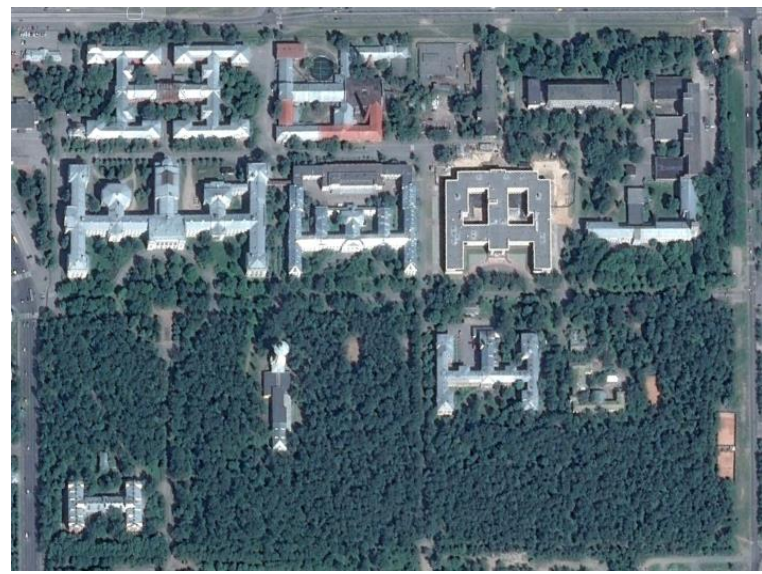

Fig. 1. Campus of SPbSTU.

The heated buildings are connected to an external heat network by means of one or more water-heating jet pumps located generally in the basement of the buildings. Hot water system in the buildings has a direct connection scheme, with the heat carrying agent coming directly from the heating source to the internal heating system of the building and hot water system as well.

\section{B. Collection of initial data}

Collection of the baseline data for the sake of convenience was carried out by means of Project Design Questionnaire. It includes the items needed for further calculations, such as recheck of the collected data.

Project Design Questionnaire is split into subdivisions according to the circuits of systems of heat supply, which are available in the buildings: radiator heating, DHW, heat supply of the ventilation systems and the section with working data of an external source of heat supply.

1st section contains HWS parameters, such as:

— estimated (designed) maximum HWS load;

- the number of hot water supply points must be known in order to check the correctness of the indicated design load;

- the initial temperature of cold water used for heating (water heating proceeds not from $0{ }^{\circ} \mathrm{C}$ );

- the required temperature of hot water is the temperature to which water must be heated.

- cold water pressure at the input to check the sufficiency of pressure in all points of the internal HWS system;

- cold water input pipeline diameter is needed to check the sufficiency of the throughput capacity of the existing input because after reconstruction the consumption of cold water will increase on account of the HWS needs; 
2nd section_contains parameters of the water heating system;

- estimated (deigned) maximum load of the heating circuit;

- the structural volume of the building is a required parameter for verifying estimation of the correctness of the estimated maximum load;

- temperature pattern of operation of the in-house heating circuit;

- building height, i.e. the height of the internal heating system is used to understand which "column of water" needs to be maintained in the return pipeline to keep the system running;

3rd section contains parameters of the ventilation assemblies' heat supply systems and/ or air curtains, if such are present at the facility. This section is virtually identical to the second.

4th section contains the data on operation of the external heat networks, to which the facility is connected:

- winter temperature mode of operation of the external heat network is used for calculating the equipment of heating circuits and heat supply of the ventilation units. It is essential to know "the actual" temperature pattern of the network operation since it affects the estimation of the heat carrier consumption for the heat supply needs and correct choice of the equipment diameter;

- summer temperature pattern of the external heat network is used for estimating the equipment for the HWS circuit because hot water must also be available in heat surplus period, i.e. in summer;

- heat carrier pressure parameters in the feeding and return pipeline of the heat network at the building's input (before AHSU) and, consequently, minimally guaranteed heat carrier pressure difference at the input. The latter parameter is critical since its value affects the choice of the heat supply systems' connection method and directly influences the choice of the equipment diameters;

- also recorded in the report form the information on existence of single- or three-phase voltage on the facility's main distribution panel as well the presence or absence of the heat energy meter;

- information is given on the size of the AHSU for further designing and planning of the AHSU layout with due regard to the actual environment and conditions.

On the basis of the Questionnaire, data collection on each of buildings was carried out.

Unfortunately, it was not possible to collect all necessary data on some of the buildings, because no project or other technical documentation was available. Some data were found in the documents received from the Project Survey Board. Generally, it was necessary to survey each building and to collect the demanded information "as is".

Also, it was not always possible to receive the archives about daily indications of Metering of Thermal Energy in the buildings connected to own University boiler, because it was either not installed or for some reason was not working.

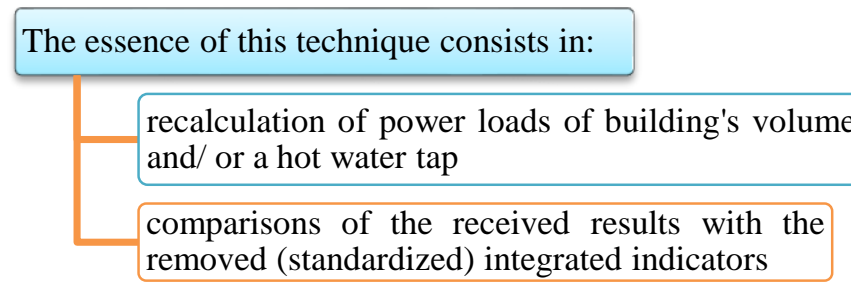

\section{Recheck of the collected and basic data}

In 19 considered buildings, there are 32 water-heating jet pumps, 9 of which have DHW, whereas others do not. We found out that at the moment the majority of buildings switched to alternative sources of DHW, in particular, the buildings use electric heating boilers and refused the centralized system of DHW. Practically in all such buildings, the internal system of DHW has been completely remade under new conditions and it is impossible to restore the former scheme with small expenses.

Also according to the obtained basic data, total heating load of the buildings is about $20.4 \mathrm{MW}$, but according to the integrated calculation executed taking into account a reserve of $18 \%$, total heating load is $16.55 \mathrm{MW}$.

Total load of DHW systems is only $3.26 \mathrm{MW}$; that is almost twice less than the data from the initial information. As a result of carrying out test calculations, we received the data from 19 buildings in which there are 32 water-heating jet pumps for systems of heating and 9 buildings are connected to the systems of DWH. Settlement maximum loads of each contour have been defined.

Special attention was paid to collection of information on the actual operating modes of the source of heat supply - the University boiler house. It has been established that the heat carrier moves from heat supply source in thermal networks with temperature conditions of boiler - 85/60 and the hydraulic control supported by water pump on a source does not provide normal pressure difference in the points of connection of the buildings to an external thermal network (Fig.2).

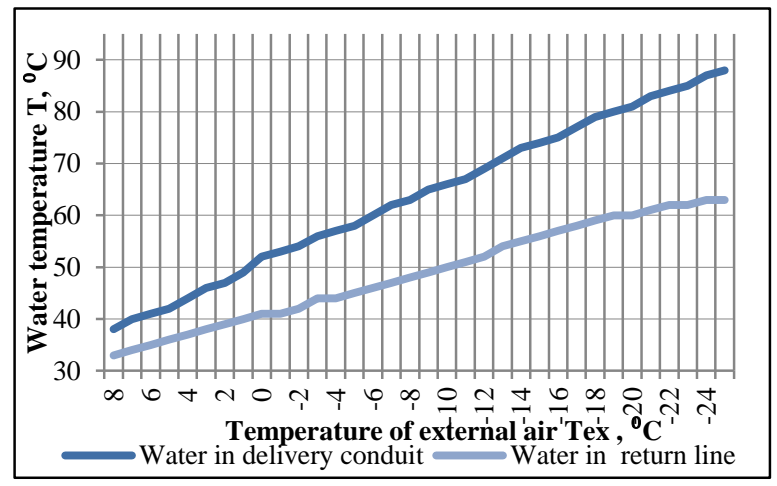

Fig. 2. Dependence of the temperature of the outside air and temperature in the delivery conduit and return line.

Generally, it is connected with the outdated and worn-out equipment which is installed in the boiler house. Considering the actual operating modes of the existing boiler house, it is possible to draw a conclusion that in further design it is technically impossible to use the independent scheme of 
connection of contours of the heating of buildings to a heating source.

\section{Check of validity of technical characteristics}

To check the reliability of the collected data, the technique recommended and being widely used in Scandinavia and the Baltic States was applied. It suits us too, as climatic conditions are almost identical.

\section{E. The check examples based on data}

Basic data were obtained in the building "Hydrotechnical building-2" (Fig.3):

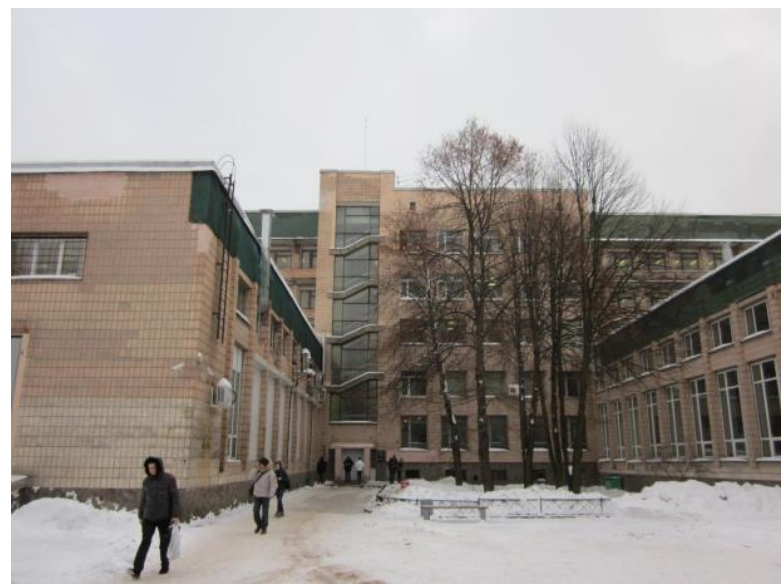

Fig. 3. "Hydrotechnical building-2" at the campus of SPbSTU.

- Max. heat load of the system of hot-water heating - $\mathrm{Q}_{\mathrm{h}}$ $=2500 \mathrm{~kW}$;

- Architectural volume of the building - V=61,090 $\mathrm{m}^{3}$.

Proceeding from the obtained data, it turns out that 0.041 $\mathrm{kW} / \mathrm{m}^{3}$ is used for heating, which is almost twice higher than normal average values, which for our region is in the range of $0.020-0.024 \mathrm{~kW} / \mathrm{m}^{3}$ depending on thermal conductivity of the cladding structures.

For the estimation we accepted the coefficient equal to 0.021 $\mathrm{kW} / \mathrm{m}^{3}$ and received the designed load of the heating system to equal $1,300 \mathrm{~kW}$.

The following data were obtained on the building "House of Scientists" (Fig.4):

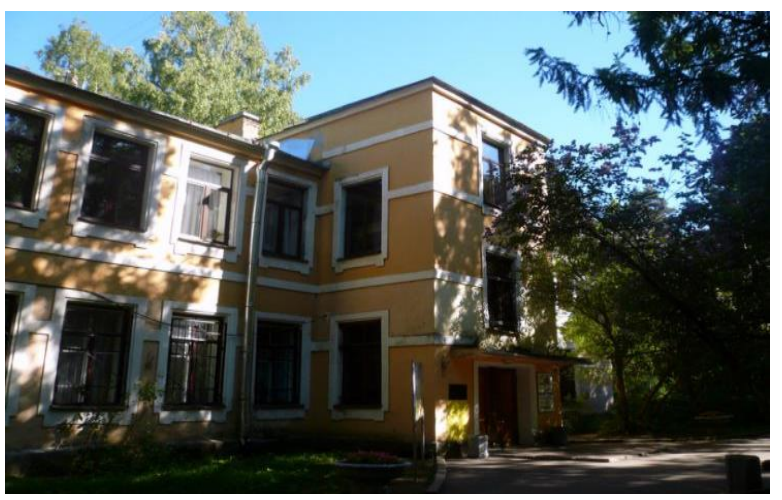

Fig. 4. "House of Scientists" at the campus of SPbSTU.
- Max. heat load of the system of hot-water heating $-Q_{h}=$ $32 \mathrm{~kW}$;

- Architectural volume of the building - V=12,541 $\mathrm{m}^{3}$.

Based on the data obtained, it was concluded that for hot water preparation is used $0.003 \mathrm{~kW} / \mathrm{m}^{3}$ of heat energy, this is several times smaller than normal average value. Calculated by average value $0.021 \mathrm{~kW} / \mathrm{m}^{3}$, practical design load of hot water heating system will be equal to $263.4 \mathrm{~kW}$.

The application of this method will clearly give strong scatter in the data, suggesting that the collected initial (design) data contain mistakes or may not correspond to the present state of affairs in the buildings.

The executed calculations showed, which parameters and in what buildings raise doubts, and in each case additional research of buildings was performed, basic data were corrected and as a result the specification was developed containing the validated basic data and requirements for the further stage - to calculate and select the equipment of the Automated Individual Thermal Points.

Fig. 4 shows the ratio of the heat load for heating in $\mathrm{kW}$ to the building volume for each building at the campus of SPbSTU. It is clearly seen that the heat energy consumption for majority of buildings are higher than the average for the region.

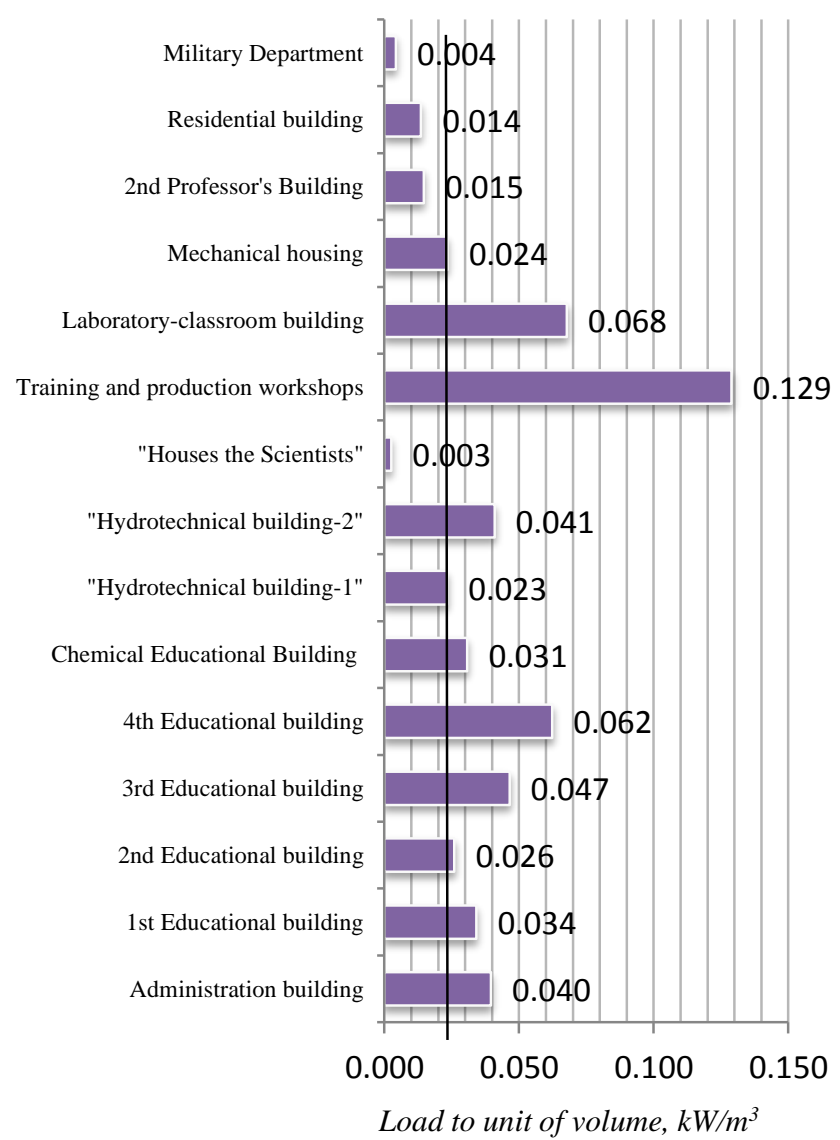

Fig. 5. Ratio of the heat load for heating in $\mathrm{kW}$ to the building volume for each building. 
Fig. 6 shows the ratio of the thermal load to the point of use of hot water. There are some deviations, which indicate the need for modernization of building heating systems.

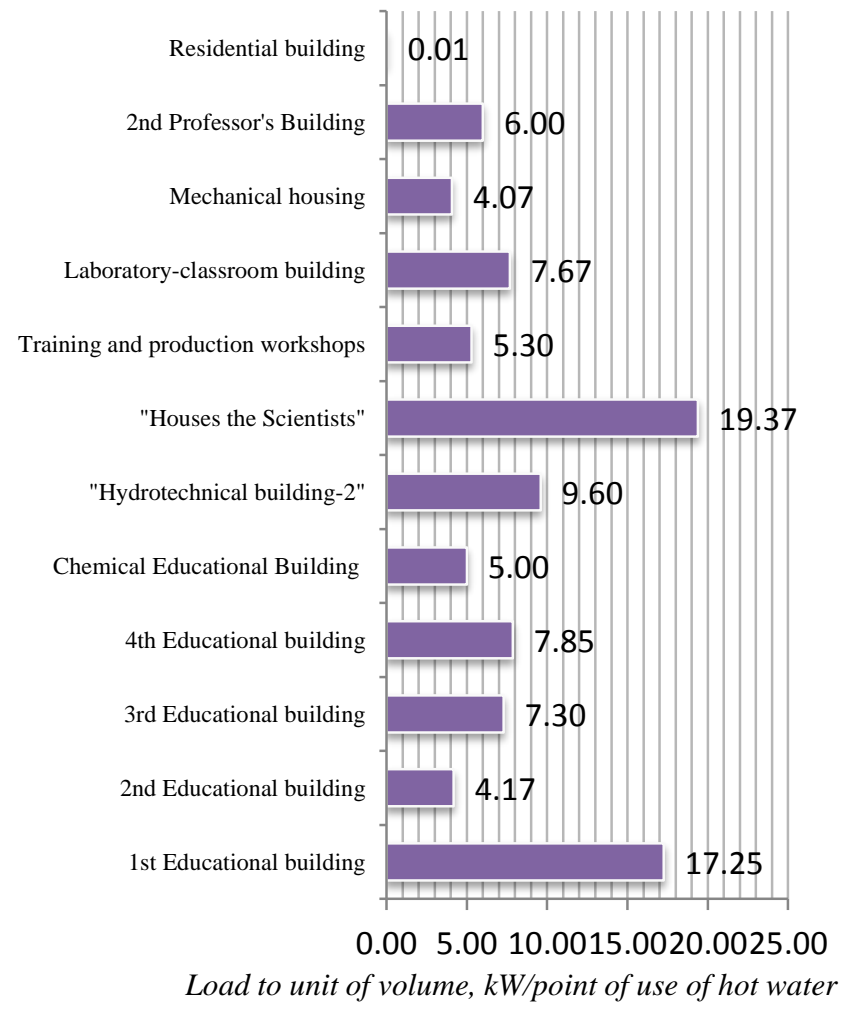

Fig. 6. Ratio of the thermal load to the point of use of hot water.

\section{F. Analysis of economic indicators}

The obtained data for 2013 from the engineering service boiler house of the University are as follows: it provided central platform with $35,623,818.11 \mathrm{kWh}$ of thermal energy, in the money expression it is $688,885.81 €$ (the rate of exchange on or before January 15: $1 €=77.96$ RUB [22]).

By using automatic equipment, which allows adjusting the system depending on the weather conditions, predicted savings could be about $15 \%$ per year, in money expression it will be $103332.87 € /$ year. The practice of using such systems in the buildings, which are not occupied around-the-clock, shows that the economy could be already about $30 \%$, in money expression it will be $206,665.74 €$.

\section{G. Past experience}

An experiment was already carried out on the Polytechnical University campus in 2014 on the reconstruction of an individual thermal unit at the Gidrokorpus-2 (Fig.7, Fig.8).

TABLE I

DATA ON CONSUMPTION OF HEAT ENERGY

\begin{tabular}{|l|l|}
\hline Actual consumption of heat energy, kWh: & $60,010.8$ \\
\hline Calculated consumption of heat energy , kWh: & $136,187.3$ \\
\hline Calculated cost, $€$ & $2,127.08$ \\
\hline Actual cost, $€:$ & 937.21 \\
\hline Cost-effectiveness, $€:$ & $1,189.87$ \\
\hline Cost-effectiveness, \%: & 55.94 \\
\hline
\end{tabular}

Measurements in 20 days, from 23.04.14 till 12.05.14, were made (Table 1).

Thus, the consumption decreased by more than $50 \%$. But it is still impossible to take these data seriously, because measurements are made in May 2014, when fluctuations of temperature during the day were more than $10{ }^{\circ} \mathrm{C}$. It will be possible to judge on the efficiency with certainty only after a full heating period.

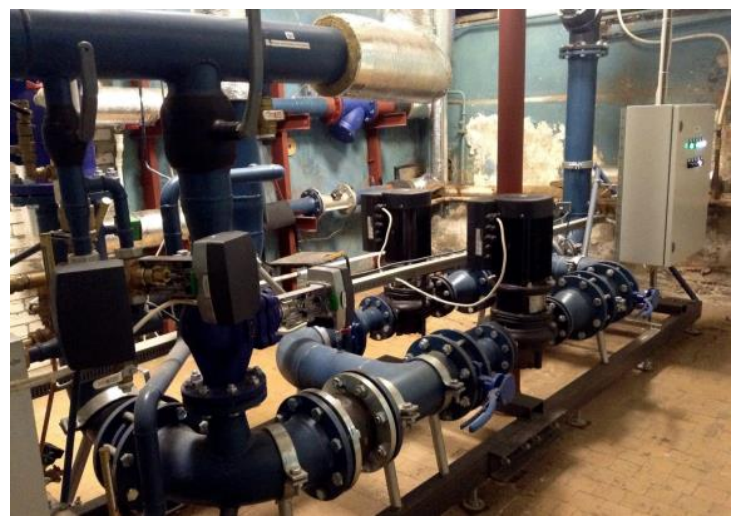

Fig. 7. Individual thermal unit in the Gidrokorpus-2.

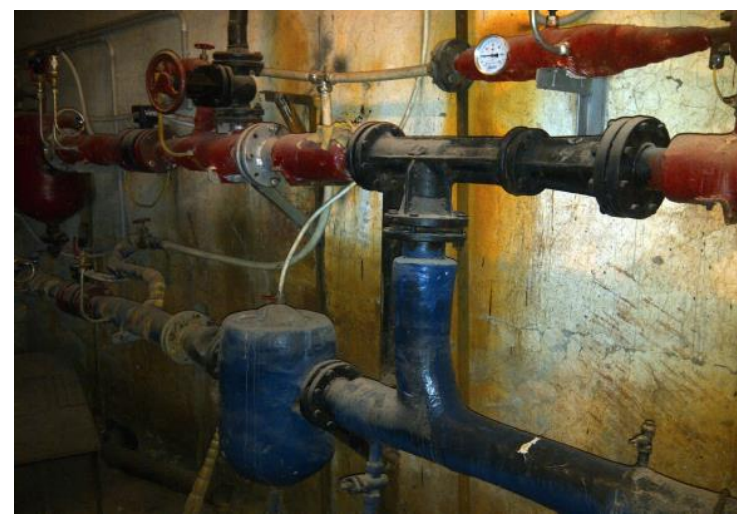

Fig. 8. Previous individual thermal unit in the Gidrokorpus-2.

\section{CONCLUSIONS}

1. Considering the actual operating modes of the existing boiler house, it is possible to draw a conclusion that in further design it is technically impossible to use the independent scheme of connection of the buildings heating system, without modernization of the heating source;

2. Taking into account the data on the existing characteristics of the heating systems and thermal characteristics of the network, the conclusion is that first of all the process of reconstruction of heat supply system of the central platform should start with the normalization of the heat consumption at the end user, that is, buildings connected to the heating network;

3. Based on the economic indicators, we can assume that the potential energy saving measures for heating systems of the central platform of SPbSTU are available. So it is reasonable to develop a program for the reconstruction of the heating systems of the Central platform of SPbSTU. 


\section{REFERENCES}

[1] "Ob jenergosberezhenii i o povyshenii jenergeticheskoj effektivnosti i o vnesenii izmenenij $\mathrm{v}$ otdel'nye zakonodatel'nye akty Rossijskoj Federacii," Federal'nyj zakon N 261-FZ ["About energy saving and energy efficiency improvements and introduction of amendments to certain regulatory actof the Russian Federation," Federal Law N 261-FZ], 2009.

[2] V. Granovskiy, "Jenergojeffektivnye sistemy otoplenija: tendencii, praktika, problem" ["Energy efficient heating systems: trends, practice, problems"], AVOK, vol. 8, pp. 40-47, 2011.

[3] V. Jakubson, "Jenergojeffektivnost' inzhenernyh setej zdanij" ["Energy efficiency of building services systems"], Magazine of Civil Engineering, vol. 3 (38), $5 \mathrm{p}, 2013$.

[4] R. Amerkhanov, Ye. Adadurov, A. Denisova, "Analiz sistemy teplosnabzhenija s kompleksnym ispol'zovaniem al'ternativnyh istochnikov jenergii" ["Analysis of Heat Supplying System with a Complex Application of Alternative Power Supply Sources"], Izvestija vysshih uchebnyh zavedenij. Jelektromehanika, vol. 1, pp. 61-63, 2004.

[5] V. Stennikov, E. Sennova, T. Oshchepkova, "Metody kompleksnoj optimizacii razvitija teplosnabzhajushhih system" ["Complex optimization methods of heat supply system development"], Izvestija Rossijaskoj Akademii Nauk. Jenergetika, vol. 3, pp. 44-54, 2006.

[6] A. Potapenko, E. Potapenko, "Vozmozhnosti povyshenija jenergojeffektivnosti processa otoplenija zdanij $\mathrm{v}$ avtomatizirovannyh ITP" ["The possibilities of increasing the efficiency of heating the buildings in the automated individual heating units"], Izvestija vysshih uchebnyh zavedenij. Problemy jenergetiki, vol. 5-6, pp. 79-88, 2005.

[7] A. Avsjukevich, "Jenergojeffektivnost i jenergosberezhenie v sistemah teplosnabzhenija" ["Energy efficiency and energy saving in heat supply systems"], Construction of Unique Buildings and Structures, vol. 2 (7), pp. 40-54, 2013.

[8] E. Anissimova, "Jenergojeffektivnost' teplovogo rezhima zdanija pri ispol'zovanii optimal'nogo rezhima preryvistogo otoplenija" ["Energy efficienty of temperature conditions for building at optimum intermittent central heating use"], Vestnik Juzhno-Uralskogo gosudarstvennogo universiteta. Serija: stroitel'stvo i arhitektura, vol. 38 (297), pp. 55-59, 2012.

[9] N. Koval'nogov, A. Rtishheva, E. Cynaeva, "Avtomatizirovannaja sistema optimal'nogo upravlenija otopleniem uchebnogo zavedenija" ["The computerized system of optimal control of heating of an educational institution"], Izvestija vysshih uchebnyh zavedenij. Problemy jenergetiki, vol. 3-4, pp. 100-107, 2007.
[10] S. Kotov, V. Nikitin, V. Stennikov, "Opyt realizacii proekta "Rekonstrukcija sistemy teplosnabzhenija rajona Novo-Lenino g. Irkutska na osnove jenergosberegajushhih tehnologij"" ["Experience of realization of the project "Reconstruction of heating system Novo-Lenin district of Irkutsk based energy-saving technologies"'], Jenergosberezhenie, vol. 2, pp. 58-62, 2001.

[11] S. Sergeeva, "Prognozirovanie zatrat na rekonstrukciju sistem teplosnabzhenija pri izmenenii parametrov nadezhnosti teplovoj seti" ["Forecasting of costs of reconstruction of systems of heat supply at change of parameters of reliability of a thermal network"], State University of Architecture and Civil Engineering of Voronezh, Voronezh, Russia, 2007.

[12] G. Petrakov, K. Slepchenok, "Sistemy teplosnabzhenija Sankt-Peterburga na sovremennom jetape i vozmozhnosti ejo mozhernizacii" ["Systems of heat supply of St. Petersburg at the present stage and possibility of its mozhernization"], Magazine of Civil Engineering, vol. 7, pp. 26-29, 2009.

[13] V. Afanasjev, V. Kovalev, V. Tarasov, V. Tarasova, D. Fedorov, "Issledovanie rashoda teplovoj jenergii na otoplenie zdanij" ["Statistical analysis of the heat flow in heating"], Vestnik chuvashskogo universiteta, vol. 2, pp. 10-18, 2014

[14] O. Samarin, N. Zajcev, "Otoplenie i konstruktivnye osobennosti zdanij" ["Heating and design features of buildings"] Santehnika, otoplenie, kondicionirovanie, vol. 9 (105), pp. 50-53, 2010.

[15] V. Murgul, D. Vuksanovic, V. Pukhkal, N. Vatin, "Development of the ventilation system in historical buildings of St. Petersburg," Applied Mechanics and Materials, vol. 633-634, pp. 977-981, 2014.

[16] V. Murgul, D. Vuksanovic, N. Vatin, V. Pukhkal, "The use of decentralized ventilation systems with heat recovery in the historical buildings of St. Petersburg," Applied Mechanics and Materials, vol. 635637, pp. 370-376, 2014.

[17] V. Pukhkal, N. Vatin, V. Murgul, "Centralized natural exhaust ventilation systems use in multi-story residential buildings," Applied Mechanics and Materials, vol. 680, pp. 529-533, 2014.

[18] D. Vuksanovic, V. Murgul, N. Vatin, V. Pukhkal, "Optimization of microclimate in residential buildings," Applied Mechanics and Materials, vol. 680, pp. 459-466, 2014.

[19] N. Vatin, D. Nemova, A. Kazimirova, K. Gureev, "Increase of energy efficiency of the building of kindergarten," Advanced Materials Research, vol. 953-954, pp. 1537-1544, 2014

[20] N. Vatin, D. Nemova, D. Tarasova, A. Staritcyna, "Increase of energy efficiency for educational institution building," Advanced Materials Research, vol. 953-954, pp. 854-870, 2014.

[21] N. Vatin N, M. Petrichenko, D. Nemova, A. Staritcyna, D. Tarasova, "Renovation of educational buildings to increase energy efficiency," Applied Mechanics and Materials, vol. 633-634, pp. 1023-1028, 2014.

[22] Centralnyj bank Rossijskoj Federacii: Kursy valjut [Central bank of the Russian Federation: Exchange rate]. [Online]. Available: http://www.cbr.ru. [Accessed: Jan. 15, 2015] 